Article

\title{
Energy Modelling and Calibration of Building Simulations: A Case Study of a Domestic Building with Natural Ventilation
}

\author{
Carolina Aparicio-Fernández ${ }^{1,+}$, José-Luis Vivancos ${ }^{2, *,+}$, Paula Cosar-Jorda ${ }^{3}$ and \\ Richard A. Buswell ${ }^{3}$ D \\ 1 Departamento de Construciones Arquitectonicas, Universitat Politècnica de València, Camino de Vera s/n., \\ 46022 Valencia, Spain \\ 2 GIDDP, Departamento de Proyectos de Ingeniería, Universitat Politècnica de València, Camino de Vera s/n., \\ 46022 Valencia, Spain \\ 3 School of Architecture, Building and Civil Engineering, Loughborough University, \\ Loughborough LE11 3TU, UK \\ * Correspondence: jvivanco@dpi.upv.es; Tel.: +34-963879860 \\ + These authors contributed equally to this work.
}

Received: 30 July 2019; Accepted: 27 August 2019; Published: 31 August 2019

\begin{abstract}
In this paper, the building energy performance modelling tools TRNSYS (TRaNsient SYstem Simulation program) and TRNFlow (TRaNsient Flow) have been used to obtain the energy demand of a domestic building that includes the air infiltration rate and the effect of natural ventilation by using window operation data. An initial model has been fitted to monitoring data from the case study, building over a period when there were no heat gains in the building in order to obtain the building infiltration air change rate. After this calibration, a constant air-change rate model was established alongside two further models developed in the calibration process. Air change rate has been explored in order to determine air infiltrations caused by natural ventilation due to windows being opened. These results were compared to estimates gained through a previously published method and were found to be in good agreement. The main conclusion from the work was that the modelling ventilation rate in naturally ventilated residential buildings using TRNSYS and TRNSFlow can improve the simulation-based energy assessment.
\end{abstract}

Keywords: energy demand; residential buildings; window opening; natural ventilation; air infiltration rate; calibrated simulation; TRNSYS

\section{Introduction}

Heating, ventilation, and air-conditioning of buildings account for a significant part of global energy consumption [1]. Studies have determined that buildings represent more than $40 \%$ of total energy consumption in the European Union [2,3]. Efforts have been made to reduce the energy demand of buildings by reducing losses through the envelope, generally through improving insulation. Energy strategies have emerged at a European level, with building energy certifications becoming a requirement in order to implement energy audits in order to apply energy saving measures [3].

Energy demand reduction in domestic buildings is a key international issue, both to decrease carbon emissions and to improve energy security, but also to the householder, who faces increasing energy bills. Space heating and air conditioning are responsible for the largest energy demand in cold and hot climates, respectively. In both cases, balancing air infiltration is key to ensure both low energy demand and a healthy internal environment. In domestic dwellings where ventilation is still supplied by purge ventilation (UK or Spain for example), ventilation practices and rates vary significantly. 
Methods that can provide better estimates of air change rates on a house by house basis are valuable when understanding energy demand reduction measures in the home [4]. The most significant energy losses occur through the envelope, due poor insulation, ventilation, and infiltration. Additionally, studies have shown that losses due to air leaks can generate problems of lower thermal comfort, in addition to a deterioration in ventilation systems [5].

Methods have been developed to determine the building air change rate (ACR) in residential buildings [1] and its impact on the energy performance studied within cold climate countries [5]. The most widespread technique used is the blower door test that quantifies the flow of air due to losses when a pressure difference is applied in a sealed building. There have been several infiltration studies over the last few decades [6] and there are standards to govern the determination of the air infiltration rate, the most utilized being the European Standard EN 13829 [7].

The quantification of ventilation rates has been a matter of interest in research over the last century, however there is little work evaluating how purge ventilation and behavioral patterns affect whole house energy consumption [4]. Although other measurement techniques, such as use of tracer gas, and steady-state analysis of $\mathrm{CO}_{2}$ concentrations [8], have been developed, the main drawbacks are usually the cost and on-site implementation. Also, these measurement methods limit the estimation of infiltration to a specific moment and are unable to characterize a wide range of building operating conditions usually required in modelling and simulation $[4,9]$.

Although studies indicate that heating energy demand derived from air infiltration can be considerable [6], the oversimplification of its treatment in modelling and analysis is recognized [1,10-12]. In residential buildings where natural ventilation is not controlled, the prediction of air change rate is complicated by its dependence on temperature difference and wind speed. There are studies that have shown the variability of infiltration rates [13] that depend on window position and local wind conditions and therefore fluctuate considerably. Simple representations of ventilation and infiltration rates are therefore unlikely to be adequate [14].

UK building regulations require that the airtightness must be less than $10 \mathrm{~m}^{3} / \mathrm{m}^{2} \mathrm{~h}$ at $50 \mathrm{~Pa}$ [15]. Studies have found that there is little difference in airtightness between naturally and mechanically ventilated dwellings in the UK [16]. The infiltration rate in an UK dwelling vary between 0.02 and $2.77 \mathrm{~h}^{-1}$, and probably less than $1.13 \mathrm{~h}^{-1}$ for a detached house [17].

In the assessment field, software programs for simulating the building energy performance have become essential tools, for example, Energy Plus, DOE-2, TRNSYS (TRaNsient SYstem Simulation program), or ESP-r (Environmental Systems Performance-Research) [1,9-14,18-21], which typically assume constant air infiltration rates [12]. A number of assumptions need to be made and these can vary between buildings, hence model calibration is an important factor [19]. In the calibration process, a model is developed through observed data recorded from the real system and is adjusted to obtain predicted results in order to align with either energy demand or indoor temperature and it is systematically evaluated, the most common method being from ASHRAE [22].

This paper combines the modelling tool TRNSYS with monitoring data to generate hourly mean air change rate (ACR) estimates. The results are compared to published work [4] by the authors, to gain confidence in the method. The paper describes the approach, studies ACR in natural ventilated buildings, and the impact of ACR on energy demand.

\section{Description of the Experimental System and Methods}

\subsection{Building Description}

The two-storey house used for the study was built in 1970 and is a $140 \mathrm{~m}^{2}$ detached building sited in a residential area located in Loughborough, within the UK East Midlands (Figure 1). The living spaces are placed in the ground floor and the first floor. The ground floor area is $64 \mathrm{~m}^{2}$ (without the garage and the utility, which are not considered habitable spaces), the first floor area is $76 \mathrm{~m}^{2}$, and the height is $2.7 \mathrm{~m}$ in both levels. The house's main entrance orientation is South East. Walls 
are solid masonry for the external layer and there is insulation and plaster board on the internal side of the façade $\left(\mathrm{U}\right.$-value $\left.=0.10 \mathrm{~W} / \mathrm{m}^{2} \mathrm{~K}\right)$. The roof shape is gable roof and the area under the roof is non-habitable (U-value $=0.35 \mathrm{~W} / \mathrm{m}^{2} \mathrm{~K}$ ). The floor is covered with concrete insulation and wood $\left(\mathrm{U}\right.$-value $\left.=0.35 \mathrm{~W} / \mathrm{m}^{2} \mathrm{~K}\right)$. In addition, the internal walls are made with plaster board and mineral wool $\left(\mathrm{U}\right.$-value $\left.=0.37 \mathrm{~W} / \mathrm{m}^{2} \mathrm{~K}\right)$.

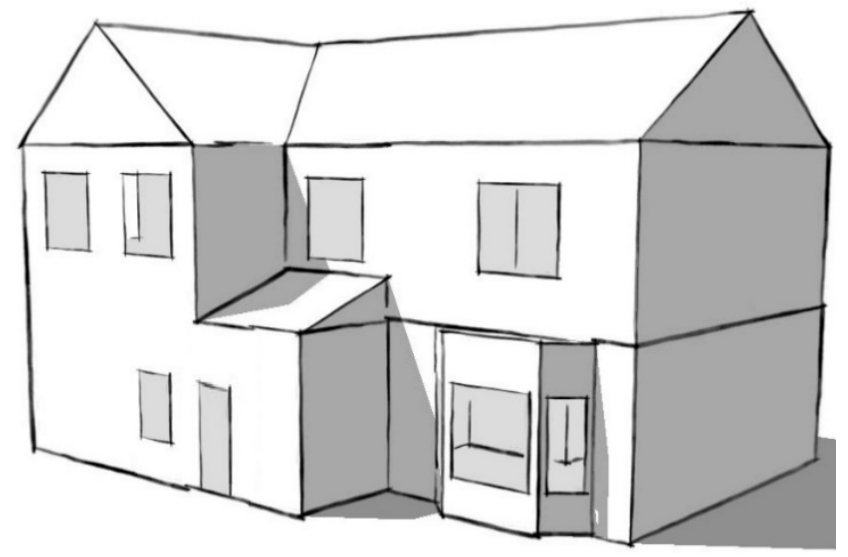

Figure 1. Model of the building in SketchUp.

Householders reported a ventilation strategy when windows were selected and opened every day for around one hour.

\subsection{Measurement and Monitoring}

This work was developed using data from the LEEDR (Low Effort Energy Demand Reduction) project home energy dataset that supports this work, together with a full description of the measurement devices, calibration details, data visualization, etc. can be freely downloaded [23]. Data from January to April 2013 was used. Measurements include gas volumetric flow rate [24], indoor temperature, electricity consumption in Watts, and window and door state (open/closed).

The indoor temperature was measured in different rooms (marked with a star in Figure 2). The average temperature of the house was obtained considering all the room sensors that have been monitored. The measured average indoor temperature is used to validate the model developed in TRNSYS.

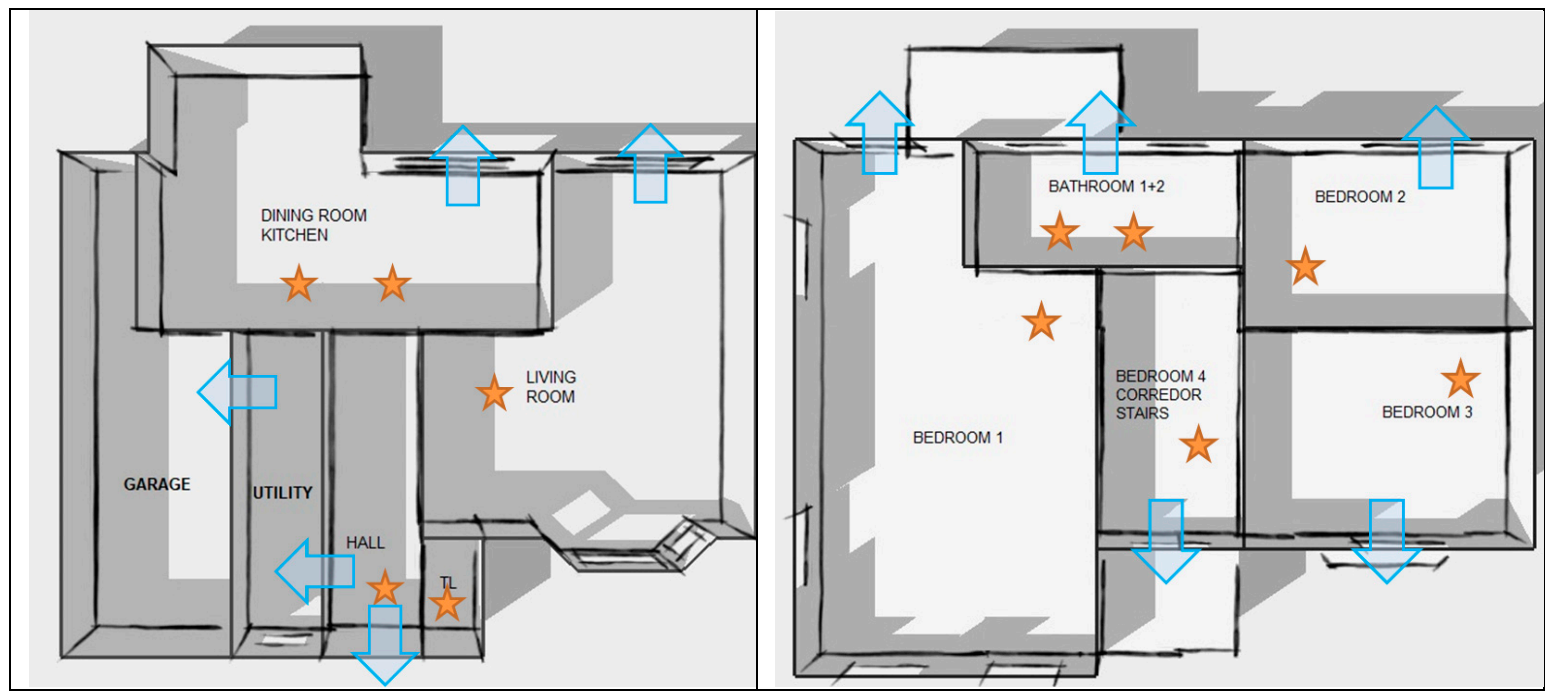

Figure 2. Temperature sensors, marked with a star, and openings of the house with the exterior, represented with a blue arrow in the (left) ground floor and the (right) first floor. 
The window and door opening sensors are shown in Figure 2, represented with a blue arrow. In total, ten opening sensors have been monitored and maintained throughout the period considered. When analyzing the data from the ten monitored dwelling openings (without taking into account period 5 (see Table 2), the following results have been obtained: the front door was open $1 \%$ of the total time: the opening dimensions of $0.80 \mathrm{~m}$ wide by $2.1 \mathrm{~m}$ high were assumed. For the window openings, an opening of $0.30 \mathrm{~m}$ of width by $1 \mathrm{~m}$ of height was assumed. The kitchen and dining room windows were opened $2 \%$ of the time and the living room window did not open during the period. In bedroom 1 windows were opened $29 \%$ of the time, in bedroom 2 the windows were not opened, in bedroom 3 windows were opened $3 \%$ of the time, and in bedroom 4 windows were opened $6 \%$ of the time (see Table 1). The bathroom window was opened $5 \%$ of the time. This data was used to evaluate the effect of natural ventilation through window operation in the building simulation to each indoor space.

Table 1. Opening time of openings of the case study.

\begin{tabular}{ccc}
\hline Room & Number of Hours & Percentage \\
\hline Front door & 24.6 & $1.6 \%$ \\
Kitchen and dining room & 44.2 & $2.9 \%$ \\
Living room & 0.02 & $0.0 \%$ \\
Bedroom 1 & 399.0 & $26.0 \%$ \\
Bedroom 2 & 0.00 & $0.0 \%$ \\
Bedroom 3 & 53.1 & $3.5 \%$ \\
Bedroom 4 & 95.6 & $6.2 \%$ \\
Bathroom & 83.1 & $5.4 \%$ \\
\hline
\end{tabular}

Non-conditioned spaces were also considered, accounting for the opening between the hall and the utility that remained opened $54 \%$ of the time and the opening between the utility and the garage, which remained opened $40 \%$ of the time.

The following data was used to inform the models:

- air temperature, humidity, solar radiation, wind velocity, and wind direction, collected from a MIDAS (Met Office Integrated Data Archive System) [25] located at Sutton Bonington, $6.5 \mathrm{~km}$ from the house;

- indoor temperature;

- gas consumption $\left(\mathrm{m}^{3}\right)$;

- $\quad$ electricity consumption (W); and,

- $\quad$ windows opening position $(0=$ closed $-1=$ opened $)$.

During the monitoring period, some data was lost through battery discharge or weak connectivity, the data was checked, and missing days of data were discarded in the analysis. To validate the TRNSYS models, sixty-four days were used (Table 2). Further information about the data treatment can be found in Buswell et al. [26].

Table 2. Data considered for calibration and validation models.

\begin{tabular}{ccccc}
\hline Period & Initial Date & Final Date & Hours & Days \\
\hline 1 & 31 January 2013 & 20 February 2013 & 504 & 21 \\
2 & 23 February 2013 & 04 March 2013 & 240 & 10 \\
3 & 06 March 2013 & 19 March 2013 & 312 & 13 \\
4 & 23 March 2013 & 26 March 2013 & 96 & 4 \\
5 & 01 April 2013 & 07 April 2013 & 144 & 6 \\
6 & 16 April 2013 & 25 April 2013 & 240 & 10 \\
\hline
\end{tabular}




\section{Simulation Methodology}

\subsection{Simulation Software}

TRNSYS-16 simulation software was used in the study, which enables the creation of a numerical model to predict and analyze different parameters of a building. The TRNFlow (TRaNsient Flow) tool was used to analyze the ventilation and infiltration. The main challenge was to estimate the house infiltration and the ventilation rates derived from the use of windows, based on opening position data. Transient states were calculated using a 10-min timestep and the results were compared to monitoring data from the modelled building.

\subsection{Model Description}

The house model was created using Type- 56 which allows the generation of a multizone building with geometric surface information. Later, the typology was changed by Type-56 TRNFlow, which calculates the ventilation and infiltration rates based on external conditions (wind velocity and direction, outdoor temperature, humidity, and solar radiation). The weather data was input in the house thermal balance, introducing the weather collected data with the TRNSYS Type-99. Thermal gains from gas and electricity consumption were considered. When using Type-56 TRNFlow, windows position data were introduced to calculate the ventilation rates.

Four house models were developed and analyzed (see Figure 3) using the specified data:

- Model 1. In this model the infiltration and ventilation were considered when windows were open on the house using Type-56 TRNFlow. An input for each window was introduced to signal when the window was opened or closed. The air infiltration is considered by estimated cracks and gaps based on the construction process and the building lifetime [27]. Figure 3 shows the developed thermal model.

- Model 2. The second model developed used TRNSYS Type-56, where air infiltration and ventilation rates were established as a constant value, the output average from Model 1 . When Model 1 was validated, the average from natural ventilation and infiltration was used as an input to develop Model 2, remaining constant all the other inputs for Model 1. The validation was based on the analysis of the indoor air temperature estimated using TRNSYS and the measured values.

- Model 3. This model was used to compare estimated energy demand to the measured gas consumption, using the Type-56 TRNSFlow. Model 1 was used removing the gas consumption measurement as a heat gain in the house. Then, a heating system was considered, where the energy demand was obtained introducing the set-point at $18.7^{\circ} \mathrm{C}$, as suggested in previous work [4]. The remaining data for window position and infiltration remains the same as in Model 1.

- $\quad$ Model 4. This model was developed using TRNSYS Type-56, where air infiltration and ventilation rates were established as a constant value, the output average from Model 1 without measured gas gains, and as in Model 3, the energy demand was obtained when the set-point is at $18.7^{\circ} \mathrm{C}$, considering the same constant value for infiltration and ventilation. In this case, temperature and energy demand can be compared with the collected data to validate the model.

Figure 4 presents the model diagram. The building was modeled with Type-56 or Type-56 TRNFlow, where geometry, construction elements, and occupancy were defined. To introduce the weather data, Type-99 was introduced, using an ascii text file with all the collected data to obtain the simulation. Input values with monitored gas, electricity, and windows data were introduced with Type-99, where the data interval is defined every $10 \mathrm{~min}$. 


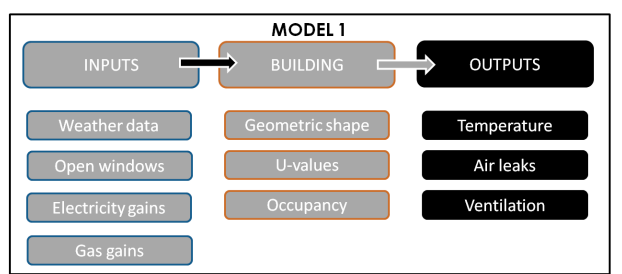

(a)

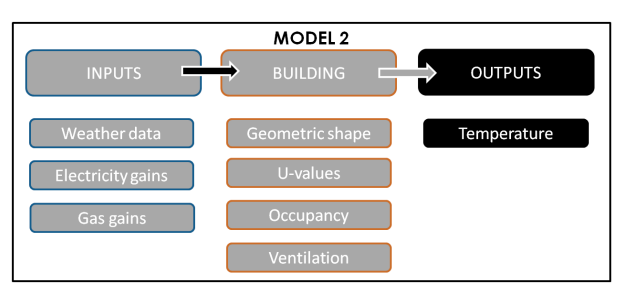

(b)

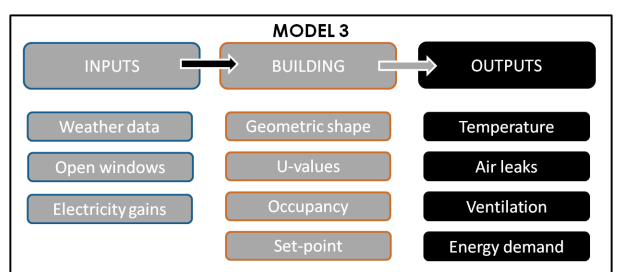

(c)

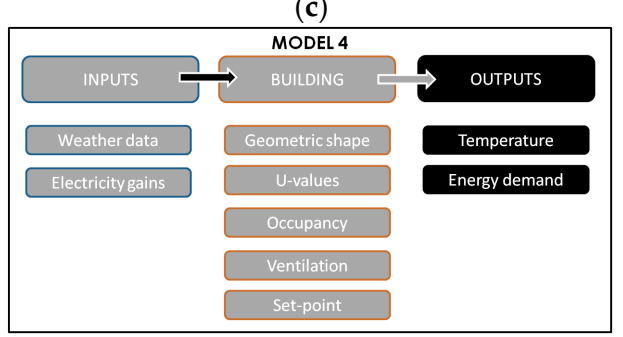

(d)

Figure 3. Elements in the four models: (a) Model 1 (infiltration and natural ventilation using TRNFlow). (b) Model 2 (constant ACR) (c) Model 3 (infiltration and natural ventilation using TRNFlow and set-point control) and (d) Model 4 (constant ACR and set-point control).

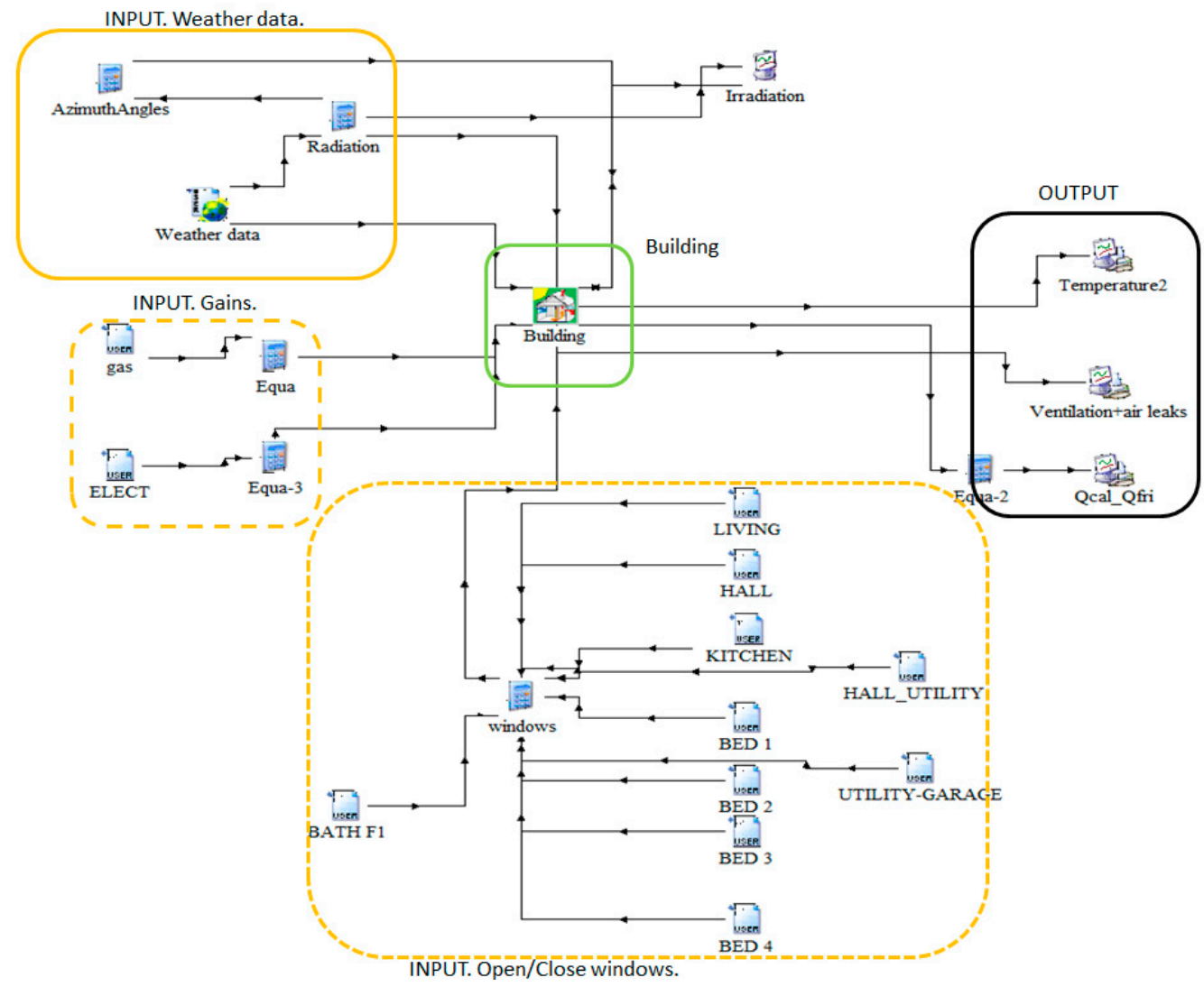

Figure 4. Building simulation diagram, when in models 3 and 4 there is no input of gas supply and in models 1 and 2 there is no energy demand output.

Several internal gains were considered. The metered volume of gas was converted to heat, assuming a calorific value [28] and boiler efficiency [29]. The space-heating schedule (on/off) was based on the measured gas consumption. The set-point used in all the heated rooms was $18.7^{\circ} \mathrm{C}$. Electricity consumption was considered to contribute to heat gains in the building [30]. Four people occupied the house, whose heat gains were estimated by applying an occupancy profile. Kitchen and Living. 
Occupation of two people in a schedule of 06:00-09:00 am and from 16:00 to 20:00 pm. Timetables for the rooms are as follows: from 0:00 to 07:00 am and from 16:00 to 24:00 pm. Occupants per dormitory are: Bedroom 1 (2 people); Bedroom 2 (No occupancy); Bedroom 3 (1 person); Bedroom 4 (1 person). The kitchen and the living room were assumed to be occupied from 07:01 to 10:00 and from 16:00 to 20:00, and the bedrooms occupancy was from 00:00 to 07:00 and from 20:01 to 23:59. Minutely data was measured for each opening, recording their position (opened or closed). Those data were used to calculate the natural ventilation through the windows. Also, an infiltration rate was considered for each façade, by estimating the area of the infiltration pathway parameter in the model during the holiday period (Period 5, see Table 2), when the house was completely vacated and all windows were closed.

\subsection{Calibration}

Several indexes are generally used to obtain the quality of the building energy simulation models, and most of them are described in the ASHRAE Guideline 14-2014 [22]. In this work, we have used normalized mean bias error (NMBE) and coefficient of variation of the root mean square error (CV(RMSE)).

NMBE (normalized mean bias error) outputs the total difference between the measured values $\left(\mathrm{m}_{\mathrm{i}}\right)$ and the simulated ones $\left(\mathrm{s}_{\mathrm{i}}\right)$. Equation (1) shows the formula to obtain NMBE values; and for calibration purposes, $p$ is suggested to be zero [31]. The approach is a normalization of the mean bias error (MBE) index scale divided by the measured values mean (m). Positive values presume that the simulation is predicting below the measurement and negative values presume that the model is over-predicting.

$$
\operatorname{NMBE}=1 / \mathrm{m} \times\left(\sum\left(\mathrm{m}_{\mathrm{i}}-\mathrm{s}_{\mathrm{i}}\right) /(\mathrm{n}-\mathrm{p})\right) \times 100(\%),
$$

where $\mathrm{n}$ is the number of measured data points, and $\mathrm{p}$ is the number of adjustable model parameters.

$\mathrm{CV}$ (RMSE) (coefficient of variation of the root mean square error) outputs the variation between the measured values $\left(\mathrm{m}_{\mathrm{i}}\right)$ and the simulated ones $\left(\mathrm{s}_{\mathrm{i}}\right)$. Equation (2) shows the formula to obtain $\mathrm{CV}$ (RMSE) values, and in this case, $\mathrm{p}$ is suggested to be one. According to [31], it represents variation of the prediction with respect to the measurement without considering or being affected when a positive value cancels a negative one, and this is the reason why it is recommended by AHSRAE Guidelines as an index to verify the accuracy of predictions [22].

$$
\mathrm{CV}(\mathrm{RMSE})=1 / \mathrm{m} \times\left(\sum\left(\mathrm{m}_{\mathrm{i}}-\mathrm{s}_{\mathrm{i}}\right)^{2} /(\mathrm{n}-\mathrm{p})\right)^{1 / 2} \times 100(\%),
$$

\section{Results}

The results obtained during the calibration process and the accuracy of the models developed were calculated by minimizing the indexes of the simulation models. For each model used in this study and for the period considered, the average of the different temperatures was obtained.

\subsection{Calibration Results}

Infiltration was estimated during a holiday period (Period 5, see Table 2), when the house was vacated for five days and the heating system was switched off. In this period, air infiltration rate was calculated to obtain similar temperatures to those measured indoors, which enabled the estimation of the infiltration model parameters. The bulk average indoor temperature was compared with the real collected data to validate the model. The air change rate $(1 / \mathrm{h})$ from the air leaks and from natural ventilation were obtained. The process was based on minimizing the coefficient of variation of the root mean square error, CV(RMSE), as defined in Equation (2).

Coefficient of variation root mean square error, CV(RMSE), and normalized mean bias error (NMBE) for Model 1 were 5.25\% and -0.38 , respectively (See Table 3). The indexes obtained were within a range of values that were considered acceptable and similar to those obtained in previous 
works using TRNSYS [19] and the ASHRAE Guideline 14 criteria to validate simulations of an entire building a NMBE and a CV(RMSE) should be lower than $10 \%$ and $30 \%$, respectively, when hourly data are compared [19].

Table 3. Coefficient of Variation root mean square error, CV(RMSE), and normalized mean bias error (NMBE) for temperature of simulation models.

\begin{tabular}{ccccc}
\hline Index & MODEL 1 & MODEL 2 & MODEL 3 & MODEL 4 \\
\hline CV(RMSE) & $5.25 \%$ & $7.37 \%$ & $6.40 \%$ & $8.74 \%$ \\
NMBE & $-0.38 \%$ & $5.71 \%$ & $-2.17 \%$ & $7.64 \%$ \\
\hline
\end{tabular}

Figure 5 shows the indoor air temperatures simulated with Model 1 and 2 versus the experimental data for the building during the holiday period (Period 5, see Table 2). According to the quantity of data introduced in Model 1, it was impossible to discriminate between air leaks and natural ventilation using windows opening data, except for the holidays period (Period 5, see Table 2). When there were no energy gains during that period, it was possible to fit the model and to obtain the air infiltration value $0.72\left(\mathrm{~h}^{-1}\right)$.

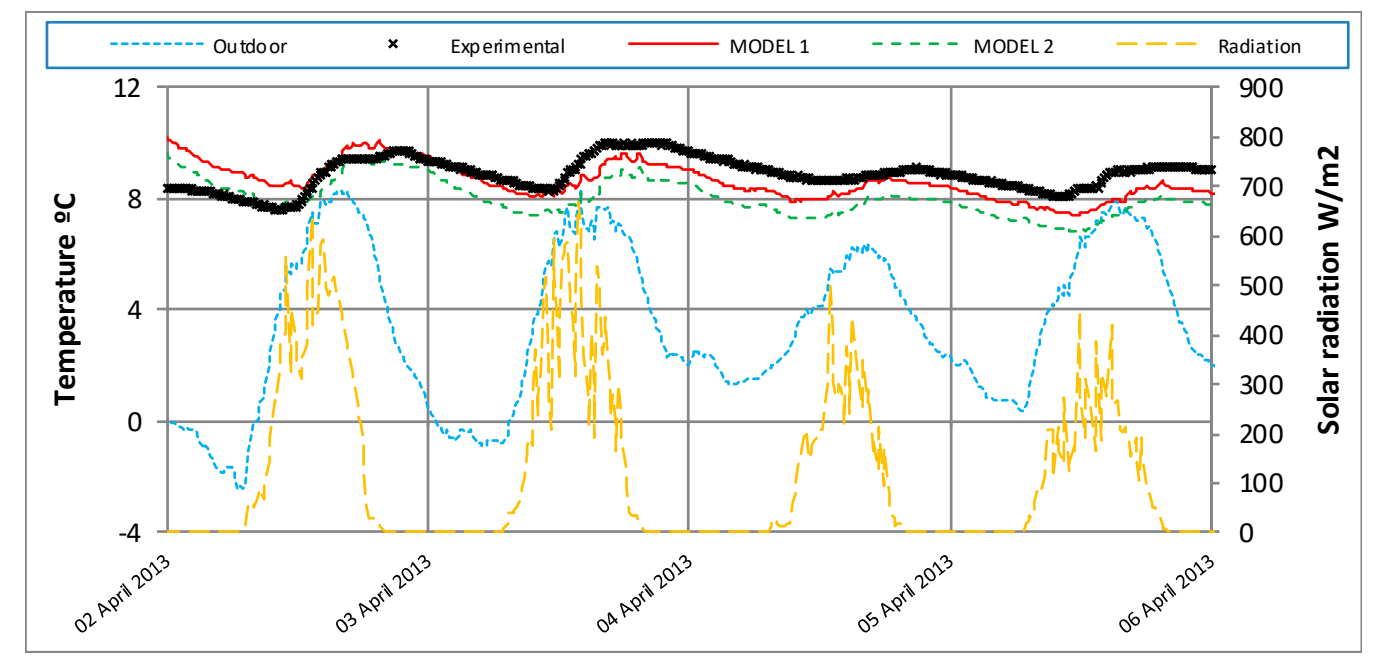

Figure 5. Indoor air temperature $\left({ }^{\circ} \mathrm{C}\right)$ with simulation models 1 and 2 versus the experimental data for the building (Period 5, see Table 2) and weather conditions (outdoor temperature $\left({ }^{\circ} \mathrm{C}\right)$ ) and solar radiation $\left(\mathrm{W} / \mathrm{m}^{2}\right)$.

\subsection{Model Validation}

After the calibration process of Model 1, the air change rate obtained was $0.72\left(\mathrm{~h}^{-1}\right)$. For each model used in this study, and for the period considered, the average of the different temperatures were obtained.

The calculated quality indexes for the Models 1 to 4 are shown in Table 2. The NMBE ranged from $-2.17 \%$ in Model 3 to $7.64 \%$ in Model 4. The CV(RMSE) ranged from 5.25\% in Model 1 to $8.74 \%$ in Model 4 . Overall, the models obtained a very good CV(RMSE) value, being lower than $10 \%$. Figure 6 shows the measured indoor air temperatures and those simulated by Models 1 and 2 . 


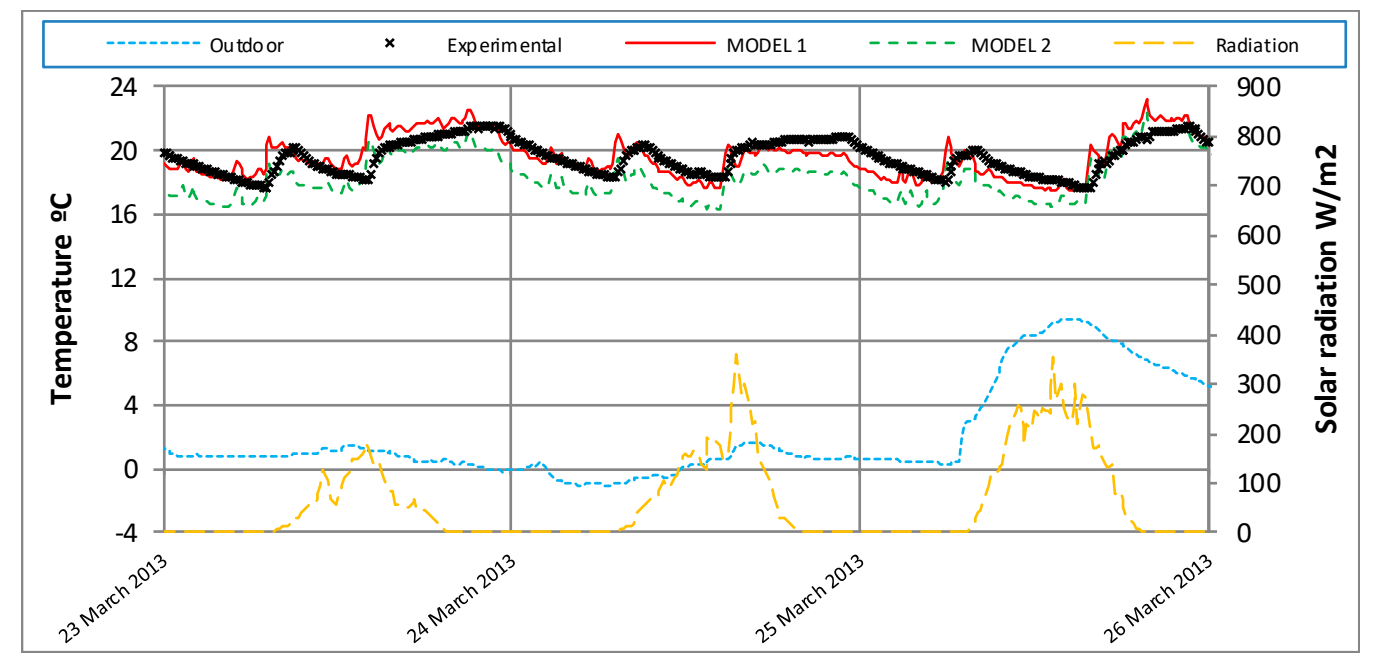

Figure 6. Indoor air temperature with simulation models 1 and 2 versus the experimental data for the building and weather conditions (outdoor temperature $\left({ }^{\circ} \mathrm{C}\right)$ and solar radiation $\left(\mathrm{W} / \mathrm{m}^{2}\right)$ ).

\subsection{Energy Demand}

Models 3 and 4 were developed to determine energy demand by assuming the ACR values obtained in Models 1 and 2, respectively (see Figure 3 for the inputs and outputs for each model). The boiler efficiency was used to obtain the energy demand for gas consumption measured in a value of 16.9 MJ (5.2 MWh), and 293 MJ (81.5 kWh) per day. Models 3 and 4 show an important difference in the output energy demand. Model 4 resulted in an energy demand of $18.6 \mathrm{MJ}$, while Model 3 resulted in a figure of $20.3 \mathrm{MJ}$. It is noteworthy to remark that despite very good fit in the indoor temperatures in Models 3 and 4, there is a remarkable difference in the energy demand results. ASHRAE Guideline 14 criteria establishes that to validate simulations of monthly natural gas when [22] CVRMSE is less than $15 \%$ [32].

Figure 7 shows the obtained hourly energy demand $(\mathrm{kJ} / \mathrm{h})$ in models 3 and 4 and measured gas when boiler efficiency was used to obtain the energy demand. Results show that Model 4 performed better than Model 3, which shows low energy demand.

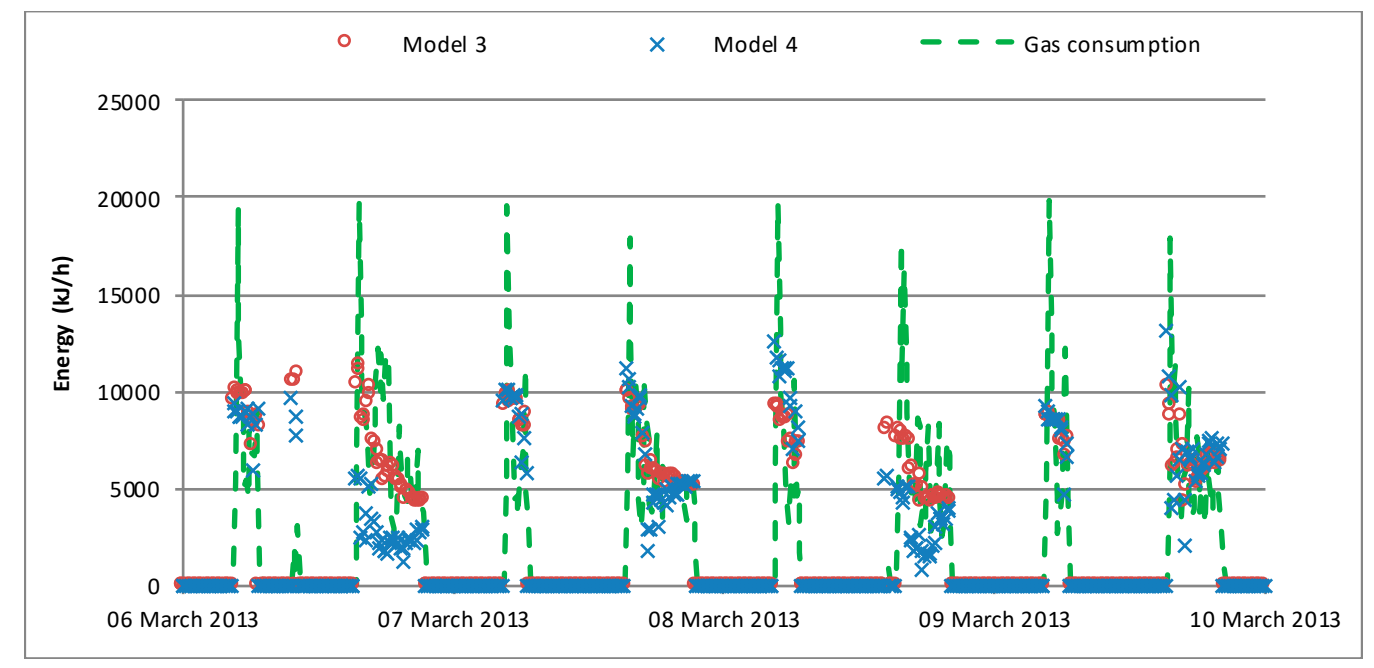

Figure 7. Energy demand hourly $(\mathrm{kJ} / \mathrm{h})$ obtained in models 3 and 4 and measured gas using boiler efficiency. 


\subsection{Air Change Rates}

Model 1 was developed further in TRNSYS using Type-56 TRNFlow, so that the dependency of ventilation and infiltration rates on wind velocity, direction, and air temperature, humidity, and solar radiation can be accounted for. An input for each window was introduced to signal when the window opens and closes.

Table 4 shows values obtained in Model 1 and in a previously published hybrid-heat balance (HHB) method [4]. The work demonstrated the influence (and variation) of opening time air change rate. Model 1 shows an air change rate lower than that in the HHB method results, except for the minimum. Figure 8 shows the air change rate $\left(\mathrm{h}^{-1}\right)$ obtained in model 1 , compared with number of windows opening, values are low compared with other methods, however, the average value used in Models 2 and 4 are in close agreement with measured values (indoor temperature and energy demand).

Table 4. Minimum, average, and maximum air change rates (ACRs) $\left(\mathrm{h}^{-1}\right)$ obtained in models and the HHB method estimation.

\begin{tabular}{cccc}
\hline Model & Minimum & Average & Maximum \\
\hline Models 1 and 3 & 0.34 & 0.61 & 1.79 \\
Models 2 and 4 & 0.72 & 0.72 & 0.72 \\
HHB method [4] & 0.04 & 1.18 & 4.86 \\
\hline
\end{tabular}

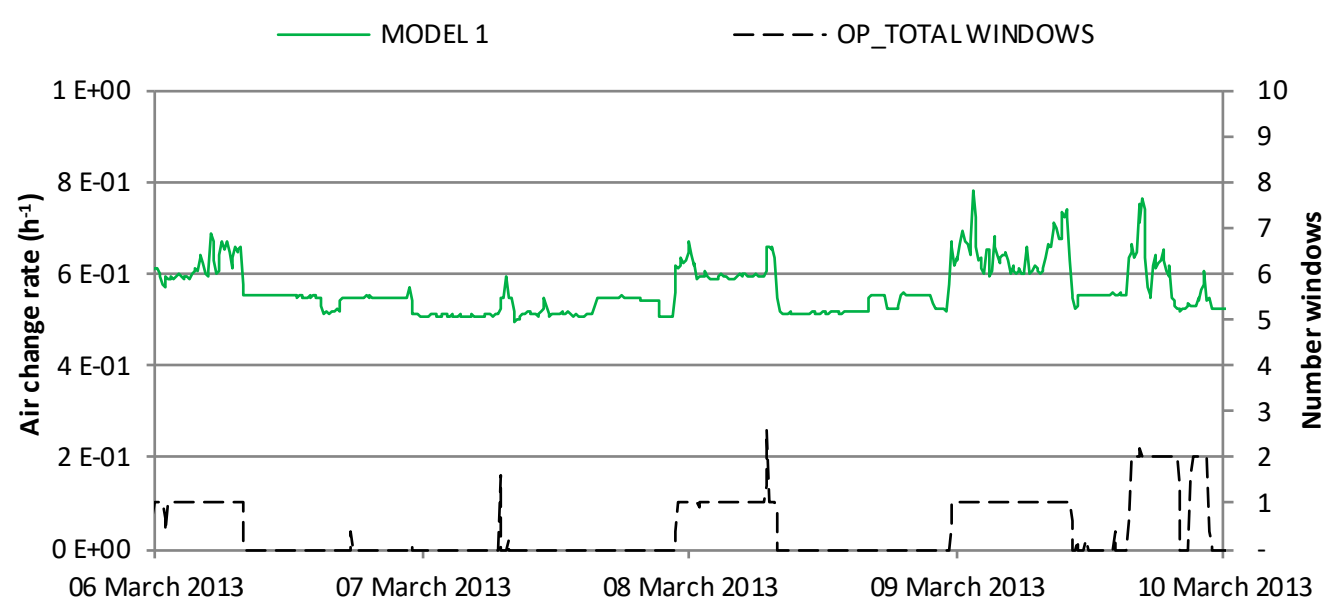

Figure 8. Air change rate $\left(\mathrm{h}^{-1}\right)$ obtained in model 1, and windows opening (number).

\section{Discussion}

TRNSYS and TRNFlow have demonstrated the possibility to obtain energy demand in buildings. Furthermore, a new approach has been tried to model air infiltration and natural ventilation input window-opening data in TRNSYS. A model developed using TRNSYS software and the TRNFlow tool was fitted based on a holiday period to obtain the building air change rate.

For the first model used in the calibration process during the holiday period, it obtained the air change rate by trying to discriminate between air infiltrations from natural ventilation due to windows openings. These results were compared with reported results using a simple steady-state heat-balance calculation method to estimate air change rates.

After the calibration process, a new model was developed using the output air change rate as a constant value for the whole period. Overall, all models obtained a very good CV(RMSE) value, lower than $10 \%$.

To estimate the energy demand, another two models were developed without using gas consumption as an input but establishing a set-point. Despite the good results in the temperature comparison, a noticeable difference was obtained in these models. Results showed that one model 
obtained a very good energy demand estimation. It would be useful to have supplemented the validation data with other methods, such as blower door tests.

Studies in residential built environments in the UK have shown that ventilation rates were dependent on windows opening and were more stable when the windows were closed [33]. There are studies which have concluded that there is a considerable number of dwellings in Europe that are under-ventilated [34]. Results showed an ACR with $0.72 \mathrm{~h}^{-1}$, which is confirmed to not be an under-ventilated dwelling (more than $0.5 \mathrm{~h}^{-1}$ ), so it would be a healthy home.

\section{Conclusions}

In this research, the energy performance of a naturally ventilated building in the UK was modelled to allow for window opening to be driven from measured data in order to improve the estimation of air change rate using TRNSYS and TRNFlow. The work represents a new approach in the consideration of window opening in the energy simulation in dwellings using measured data.

The models developed were proven to provide a reliable estimation of indoor air temperature and energy demand. The NMBE ranged from $-6.7 \%$ to $7.6 \%$ and the CV(RMSE) had a range of $5.3 \%$ to $8.7 \%$ for the period. In general, all models obtained very good CV(RMSE) values, less than $10 \%$. The average ACR calculated by the simulation was $0.7 \mathrm{~h}^{-1}$, which is not a dwelling that is under-ventilated (more than $0.5 \mathrm{~h}^{-1}$ ), so it would be a healthy home.

The potential for this approach could be for analyzing householder behavior and to provide a smart way to assess the most effective natural ventilation strategies for lower energy demand and healthy conditions.

Author Contributions: Conceptualization, P.C.-J. and R.A.B.; Data curation, P.C.-J. and R.A.B.; Formal analysis, C.A.-F. and J.-L.V.; Funding acquisition, R.A.B.; Investigation, C.A.-F.; Methodology, C.A.-F.; Project administration, R.A.B.; Resources, P.C.-J.; Software, C.A.-F.; Supervision, R.A.B.; Validation, J.-L.V. and P.C.-J.; Visualization, C.A.-F. and J.-L.V.; Writing-original draft, C.A.-F., J.-L.V., and P.C.-J.; Writing-review and editing, J.-L.V., P.C.-J., and R.A.B.

Funding: This research received no external funding.

Conflicts of Interest: The authors declare no conflict of interest.

\section{References}

1. Grygierek, K.; Ferdyn-Grygierek, J. Multi-Objective Optimization of the Envelope of Building with Natural Ventilation. Energies 2018, 11, 1383. [CrossRef]

2. Moran, P.; Goggins, J.; Hajdukiewicz, M. Super-insulate or use renewable technology? Life cycle cost, energy and global warming potential analysis of nearly zero energy buildings (NZEB) in a temperate oceanic climate. Energy Build. 2017, 139, 590-607. [CrossRef]

3. Allouhi, A.; El Fouih, Y.; Kousksou, T.; Jamil, A.; Zeraouli, Y.; Mourad, Y. Energy consumption and efficiency in buildings: Current status and future trends. J. Clean. Prod. 2015, 109, 118-130. [CrossRef]

4. Cosar-Jorda, P.; Buswell, R.A.; Mitchell, V.A. Determining of the role of ventilation in residential energy demand reduction using a heat-balance approach. Build. Environ. 2018, 144, 508-518. [CrossRef]

5. Jesús, F.M.; Irene, P.C.; Alonso, G.L.R.; Cristina, P.; Víctor, E.; De Larriva Rafael, A.; Jesica, F.A.; Jesús, D.V.M.; José, D.C.D.V.; Manuel, M.C.; et al. Methodology for the study of the envelope airtightness of residential buildings in Spain: A case study. Energies 2018, 11, 704. [CrossRef]

6. Domínguez-Amarillo, S.; Fernández-Agüera, J.; Campano, M.Á.; Acosta, I. Effect of Airtightness on Thermal Loads in Legacy Low-Income Housing. Energies 2019, 12, 1677. [CrossRef]

7. Cheng, P.L.; Li, X. Air infiltration rates in the bedrooms of 202 residences and estimated parametric infiltration rate distribution in Guangzhou, China. Energy Build. 2018, 164, 219-225. [CrossRef]

8. Hou, J.; Zhang, Y.; Sun, Y.; Wang, P.; Zhang, Q.; Kong, X.; Sundell, J. Air change rates at night in northeast Chinese homes. Build. Environ. 2018, 132, 273-281. [CrossRef]

9. Zhai, Z.; El Mankibi, M.; Zoubir, A. Review of natural ventilation models. Energy Procedia 2015, 78, $2700-2705$. [CrossRef] 
10. Han, G.; Srebric, J.; Enache-Pommer, E. Different modeling strategies of infiltration rates for an office building to improve accuracy of building energy simulations. Energy Build. 2015, 86, 288-295. [CrossRef]

11. Laverge, J.; Janssens, A. Optimization of design flow rates and component sizing for residential ventilation. Build. Environ. 2013, 65, 81-89. [CrossRef]

12. Bhandari, M.; Hun, D.; Shrestha, S.; Pallin, S.; Lapsa, M. A Simplified Methodology to Estimate Energy Savings in Commercial Buildings from Improvements in Airtightness. Energies 2018, 11, 3322. [CrossRef]

13. Pisello, A.L.; Castaldo, V.L.; Taylor, J.E.; Cotana, F. The impact of natural ventilation on building energy requirement at inter-building scale. Energy Build. 2016, 127, 870-883. [CrossRef]

14. Tronchin, L.; Fabbri, K.; Bertolli, C. Controlled Mechanical Ventilation in Buildings: A Comparison between Energy Use and Primary Energy among Twenty Different Devices. Energies 2018, 11, 2123. [CrossRef]

15. Ashdown, M.M.A.; Crawley, J.; Biddulph, P.; Wingfield, J.; Lowe, R.; Elwell, C.A. Characterising the airtightness of dwellings. Int. J. Build. Pathol. Adapt. 2019. [CrossRef]

16. Crawley, J.; Wingfield, J.; Elwell, C. The relationship between airtightness and ventilation in new UK dwellings. Build. Serv. Eng. Res. Technol. 2019, 40, 274-289. [CrossRef]

17. Jones, B.; Das, P.; Chalabi, Z.; Davies, M.; Hamilton, I.; Lowe, R.; Mavrogianni, A.; Robinson, D.; Taylor, J. Assessing uncertainty in housing stock infiltration rates andassociated heat loss: English and UK case studies. Build. Environ. 2015, 92, 644-656. [CrossRef]

18. Schulze, T.; Eicker, U. Controlled natural ventilation for energy efficient buildings. Energy Build. 2013, 56, 221-232. [CrossRef]

19. Ogando, A.; Cid, N.; Fernández, M. Energy Modelling and Automated Calibrations of Ancient Building Simulations: A Case Study of a School in the Northwest of Spain. Energies 2017, 10, 807. [CrossRef]

20. Stavridou, A.D.; Prinos, P.E. Unsteady CFD Simulation in a Naturally Ventilated Room with a Localized Heat Source. Procedia Environ. Sci. 2017, 38, 322-330. [CrossRef]

21. Klein, S.A. TRNSYS 16 Manual. Trnsys 16 2007. Available online: https://www.uni-kassel.de/maschinenbau/ fileadmin/datas/fb15/instruction_trnsys_16_exercises_2007_01.pdf (accessed on 31 August 2019).

22. American Society of Heating, Ventilating, and Air Conditioning Engineers (ASHRAE). Guideline 14-2014, Measurement of Energy and Demand Savings; Technical Report; American Society of Heating, Ventilating, and Air Conditioning Engineers: Atlanta, GA, USA, 2014.

23. Buswell, R.; Webb, L.; Cosar-Jorda, P.; Marini, D.; Brownlee, S.; Thomson, M.; Yang, S.H.; Kalawsky, R. LEEDR Project Home Energy Dataset. Available online: https://repository.lboro.ac.uk/articles/LEEDR_project_home_ energy_dataset/6176450 (accessed on 12 June 2018).

24. Buswell, R. Uncertainty in whole house monitoring. In Proceedings of the 13th International Conference of the International Building Performance Simulation Association, Chambery, France, 25-28 August 2013; pp. 2403-2410.

25. Met Office Integrated Data Archive System (MIDAS) Land and Marine Surface Stations Data (1853-current). NCAS British Atmospheric Data Centre, 2012. Available online: http://catalogue.ceda.ac.uk/uuid/ 220a65615218d5c9cc9e4785a3234bd0 (accessed on 12 June 2018).

26. Buswell, R.; Webb, L.; Mitchell, V.; Leder Mackley, K. Multidisciplinary research: should effort be the measure of success? Build. Res. Inf. 2017, 45, 539-555. [CrossRef]

27. Orme, M.; Liddament, M.W.; Wilson, A. Numerical Data for Air Infiltration E Natral Ventilation Calculations; AIVC: Coventry, UK, 1998.

28. National Grid. National Grid UK. 2018. Available online: https://www.nationalgrid.com/uk/gas/marketoperations-and-data/calorific-value-cv (accessed on 11 July 2018).

29. HHG. Home Heating Guide: Boiler Efficiency Tables. 2018. Available online: https://www.homeheatingguide. co.uk/efficiency-tables (accessed on 11 July 2018).

30. Hosni, M.H.; Jones, B.W.; Xu, H. Experimental results for heat gain and radiant/convective split from equipment in buildings. ASHRAE Trans. 1999, 105, 527-539.

31. Ruiz, G.; Bandera, C. Validation of Calibrated Energy Models: Common Errors. Energies 2017, $10,1587$. [CrossRef]

32. Hong, T.; Piette, M.A.; Chen, Y.; Lee, S.H.; Taylor-Lange, S.C.; Zhang, R.; Sun, K.; Price, P. Commercial Building Energy Saver: An energy retrofit analysis toolkit. Appl. Energy 2015, 159, 298-309. [CrossRef] 
33. Nasir, Z.A.; Colbeck, I. Particulate pollution in different housing types in a UK suburban location. Sci. Total Environ. 2013, 445, 165-176. [CrossRef] [PubMed]

34. Dimitroulopoulou, C. Ventilation in European dwellings: A review. Build. Environ. 2012, 47, $109-125$. [CrossRef]

(c) (C) 2019 by the authors. Licensee MDPI, Basel, Switzerland. This article is an open access article distributed under the terms and conditions of the Creative Commons Attribution (CC BY) license (http://creativecommons.org/licenses/by/4.0/). 